\title{
台風 0418 号通過時の宮島周辺の強風場に関する数値シミュレーション \\ Numerical Simulation of Strong Wind Fields around Miyajima during Typhoon Songda in 2004
}

\author{
丸山 敬*1 \\ 石川裕彦*2 \\ 内田孝紀*3 \\ 河井宏允 ${ }^{* 2}$ \\ 大屋裕二*4
}

Takashi MARUYAMA*1 Hirohiko ISHIKAWA*2 Takanori UCHIDA*3 ${ }^{* 3}$ Hiromasa KAWAI ${ }^{* 2}$ Yuji OHYA*4

\section{SUMMARY}

The strong wind fields around Miyajima in Hiroshima Bay were simulated numerically during Typhoon Songda in 2004. The PSU/MM5 model was used for the calculation of meso-scale regions. The strong wind that passed over the sea and blew into the Hiroshima Bay was simulated. The predicted wind fields were examined comparing with the observed records and the field investigation of damage to the houses and buildings. The calculated maximum wind speed map was well correlated to the distribution of damage rate by strong wind in Hiroshima Prefecture. Unsteady wind fields were also computed by Large Eddy Simulation in the fine region around Miyajima. The local wind characteristics caused by the topography around Itsukushima Shrine were investigated by using the calculated results. The down flow along the valley to the south of the shrine was simulated in the neutral atmospheric condition. The local wind flows around the shrine were discussed.

key words: numerical simulation, strong wind, Miyajima Island, Typhoon Songda, MM5, LES

1.はじめに

広島湾に浮かぶ宮島には世界遺産で有名な厳島神社が あり，図1に示すような南側に標高 $500 \mathrm{~m}$ を超えるかな り急峻な山の麓の入り江の奥に位置している.これまで, 厳島神社は台風による強風被害を幾度か受けており，近 年では 1991 年の台風 9119 号および 1999 年の台風 9918 号によるもの，そして，本研究で扱う 2004 年の台風 0418 号によるものが挙げられる.これらの台風について
は気象状況，被害状況などが詳しく調べられ，文献 1 3 などにまとめられている。 それらによると，厳島神社 は台風の中心が九州に上陸し，日本海に抜けるコースを たどる場合に大きな被害を受けることが多く，その危険 性が指摘されている，厳島神社周辺の強風被害に関して 原因となる風の吹き方をみてみると，台風 9119 号では 南側の谷筋を風が吹き降りた ${ }^{1)}$ ，台風 9918 号では被害の 状況および風洞実験から，強い西風が吹いた ${ }^{2)}$ ，とされ

*1 京都大学防災研究所 助教授

Disaster Prevention Research Institute, Kyoto University, Associate Professor

*2 京都大学防災研究所 教授

Disaster Prevention Research Institute, Kyoto University, Professor

*3 九州大学応用力学研究所 助手

Research Institute for Applied Mechanics, Kyusyu University, Research Assistant

*4 九州大学応用力学研究所 教授

Research Institute for Applied Mechanics, Kyusyu University, Professor

（原稿受理年月日：2005 年 11 月 14 日，採用決定 : 2006 年 4 月 14 日） 


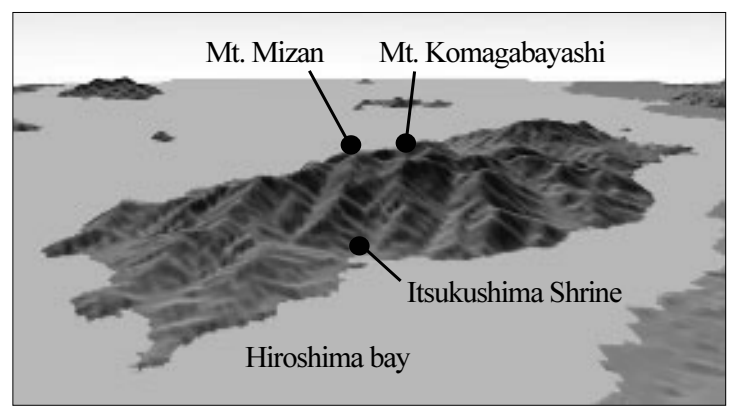

図 1 宮島の遠景（北から南を眺める）

Fig.1 Bird's-eye-view of Miyajima Island from the north

ている.さらに，台風 0418 号ではビデオ映像や被害の 状況，および目撃者の証言から，周辺の地形の影響を受 けた複雑な風が吹いていたことがわかっている ${ }^{3)}$.

本研究ではこの台風 0418 号を対象として, 日本列島 をほぼカバーする大スケールから，地形による局地的な 風の乱流場を再現できる程度の小スケールにわたる数值 シミュレーションを行い, 台風通過時の強風場を再現し た. 計算結果は気象観測值や被害調查結果と比較し, 広 島湾の宮島周辺で強風被害が発生する場合の気流性状に ついて検討を行った.

\section{2. 計算手法}

\section{1 概 要}

台風のシミュレーションには, メソスケールの気象解 析・予測のために開発された PSU/NCAR MM54)モデル （以後 MM5 と表記）を用いた. MM5 は音波を含む圧 縮系の力学方程式系と, 降水, 放射, 境界層, 乱流, 地 表面過程を計算する物理モデルで構成され，客観解析デ ータを入力として予測を行うことができ，これまでに多

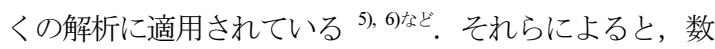
百メートル程度の計算格子幅を持った解析領域に対して, 十数分程度の時間平均值の変化をほぼ現実的に予測する ことができる. MM5 による計算領域は図 2 に示すよう に, ほぼ日本全域を覆う一辺 $2160 \mathrm{~km}$ 四方の広領域から
順次範囲を狭くし, 一辺 $30.3 \mathrm{~km}$ 四方の最も小さな解析 領域まで $4 つ の$ 領域をネスティングさせた.

一方, 宮島周辺では厳島神社付近の地形の影響を受け た局地的な強風場の解析を行うために, さらに小さな格 子解像度をもった解析領域を設定する。 ここでは，乱流 モデルとしてスマゴリンスキーモデルを用いた 0 方程式 系のラージェディシミュレーション（以後 LES と表 記）により乱流場の非定常計算を行った.

\subsection{MM5による計算}

MM5 の計算で用いた 4 つの解析領域において, 水平 方向の格子間隔はそれぞれ等間隔にとり, 最も広い解析 領域 1 では一辺 $9 \mathrm{~km}$ の格子を $240 \times 240$. 領域 2 では一辺 $3 \mathrm{~km}$ の格子を $211 \times 211$, 領域 3 では一辺 $1 \mathrm{~km}$ の格子を $91 \times 91$, 最も小さい解析領域 4 では一辺 $1 / 3 \mathrm{~km}$ の格子を 91×91 用いた．鈶直格子は，台風では背の高い対流が立 つことを考慮して上端を $50 \mathrm{hPa}$ ，約 $20000 \mathrm{~m}$ とし，地表 から上端までを 35 層に分割して下層ほど密な格子間隔 とした. 水平風速が計算される高さは, 海面上では下層 から 8, 36, 153, 137, 339, 456m ...である. 気象デー夕は, 気象庁の $20 \mathrm{~km}$ 格子領域客観解析値と 0.25 度格子の北西 太平洋日別海面水温解析データを用いた. 初期時刻は 9 月 6 日午後 9 時とし, 一番外側の領域の境界条件のみ客 観解析データを 6 時間ごとに与え，中間時刻の境界值は 線型内挿した. 計算領域内部での 4 次元データ同化は用 いていない. 海面温度は 9 月 7 日午前 9 時に切り替えた. また，ネスト領域間では内側格子の計算結果が外側格子 の計算に反映される 2 way nesting を用いた. 地面境界で は USGS（米国地質調查所）の 30 秒格子の標高データ, および植生データ（都市を含む 25 分類）を用い，地表 面過程の計算には Five-layer soil model を使用した. 雲微 物理過程には氷晶の数密度や霞まで考慮できる Reisner 2 スキームを使用した．放射過程には Cloud-radiation scheme を用い, デフォルトでは 30 分に 1 回放射計算を 行うように設定されているが，台風の進行とともに雲域 が移動することを考慮して, 10 分間隔で放射計算を行っ

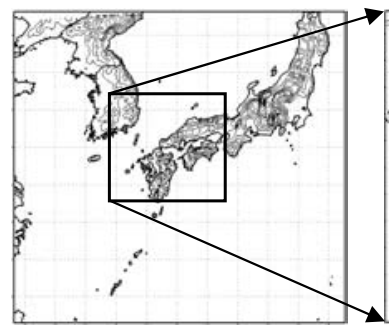

a. Region $1: 2151 \times 2151 \mathrm{~km}^{2}$

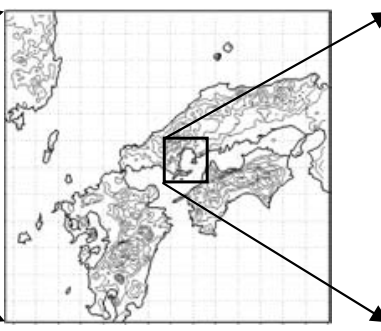

b. Region $2: 630 \times 630 \mathrm{~km}^{2}$

図 2 MM5 の計算領域

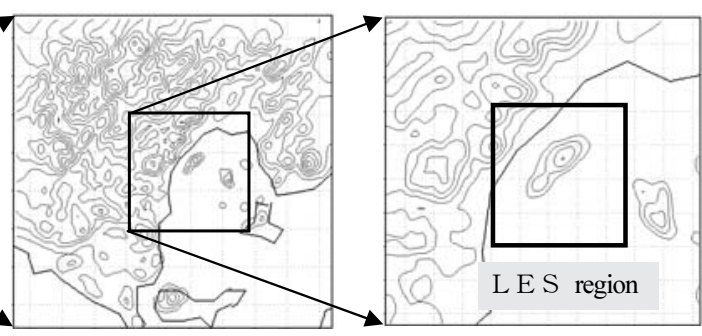

c. Region $3: 90 \times 90 \mathrm{~km}^{2}$

d. Region $4: 30 \times 30 . \mathrm{km}^{2}$ 


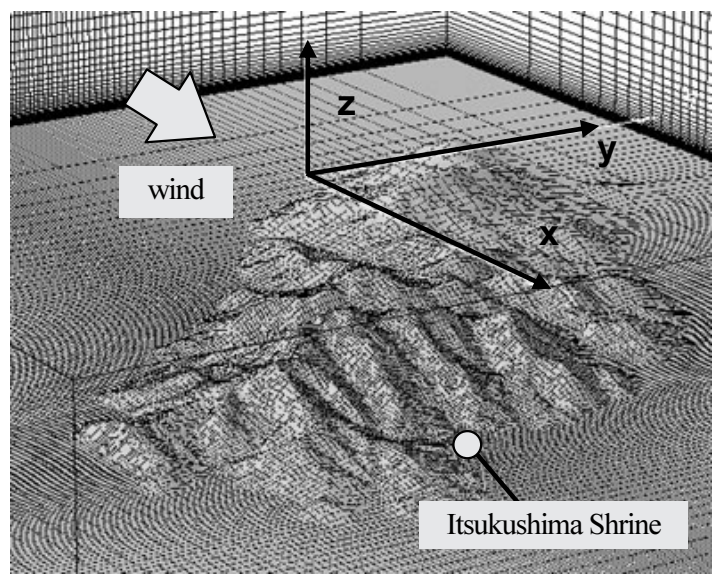

図 3 宮島周辺の L E S 解析用計算領域

Fig.3 Calculation region for LES

た．大気境界層スキームについては Eta スキームを使用 した。積雲対流パラメタリゼーションは使用していない． それぞれのモデルの詳細な説明はここでは行わないが，

MM5 の解説 (http://www.mmm.ucar.edu/mm5/documents /tutorial-v3-notes.html）などを参照されたい.

\subsection{LESによる計算}

宮島の厳島神社付近における強風乱流場を解析寸るた めに, 図 $2 \mathrm{~d}$ 中に示すような最小の解析領域をとり, LES による非定常計算を行った．計算は宮島付近で最も 強い平均風速が観測された 14 時頃を対象とし，MM5 に よる領域 4 の計算結果をもとに，図 3 に示寸ように地上 付近の平均風向となる南風が流入境界面に直交するよう 座標軸は北に向かって $\mathrm{x}$ 軸を，西に向かって $\mathrm{y}$ 軸をとっ た．計算領域の大きさは宮島を中心として南北 $13 \mathrm{~km}$, 東西 $11 \mathrm{~km}$ ，水平面内の格子数は $151 \times 151$ で不等間隔直 交格子とし，厳島神社付近で最小格子幅約 $30 \mathrm{~m}$ ，周辺に いくにしたがって最大約 $1400 \mathrm{~m}$ まで変化させた．鉛直

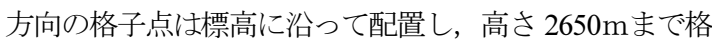
子数 41. 格子幅は地面付近で $1.8 \mathrm{~m}$ ，上方に行くにした がって $260 \mathrm{~m}$ まで大きくなる不等間隔格子を用いた．変 数配置は一般曲線座標に沿ったコロケートメッシュ系を 用いた．標高は国土地理院の $50 \mathrm{~m}$ メッシュデータをもと に与え，地表面境界ではノンスリップ条件を用いている。 ただし，実際の計算は厳島神社南側の弥山の高さ $530 \mathrm{~m}$ と，その高さでの流入平均風速を代表スケールおよび代 表風速として，レイノルズ数 10000 で行っている. 計算 コードには狭域スケールを対象に, 九州大学応用力学研 究所で開発された非定常・非線形風況シミュレータ RIAM-COMPACT ${ }^{7)}$ を用いた。

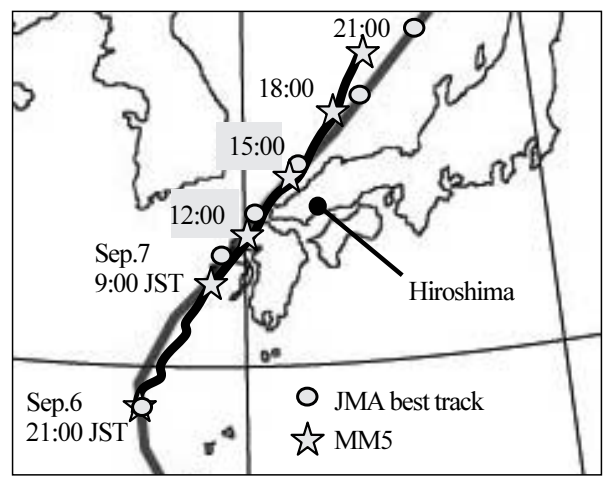

図4 台風の進路

Fig.4 Track of typhoon center

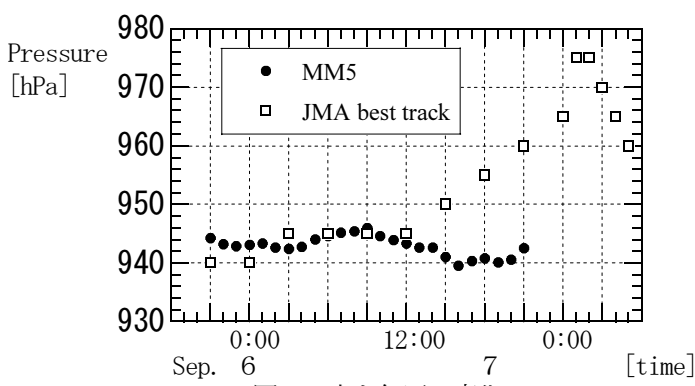

図 5 中心気圧の変化

Fig.5 Variation of typhoon center pressure

\section{3. 計算結果}

\section{1 台風のシミュレーション}

MM5 で再現された台風の経路と中心気圧を観測デー 夕と比較する. 図 4 のように経路は気象庁 best track 上り もやや南よりかつ進行が遅れ気味で, 広島周辺で強風が 発生した時刻 12 時から 15 時では, 計算された台風中心 は 30 から $40 \mathrm{~km}$ 程度, 解析值よりも南西側となった. また, 気象庁の解析では中心気圧が 12 時以降上昇して いるが，図5のように計算結果では逆に下がり，日本海 上で発達した。

広島湾付近，広島地方気象台，吳の特別地域気象観測 所および宮島消防署で観測された風向，風速，温度の台 風通過時の変化を, MM5 の領域 3 の計算結果と比較す ると図 6 のようになる. 計算值は観測地点と最も近い格 子点の值を示してある. 広島では風向変化は観測とよい 対応を示寸が，風速は計算結果が観測值の 5 割から 8 割 程度大きくなり，気温も計算結果の方が低い值を示して いる，呉では風向と温度はよい一致を示しているが，風 速は計算の方が大きくなる。広島地方気象台は海岸から は約 $5 \mathrm{~km}$ 内陸に位置し，周りにはビルが建ち並ぶ市街 地の中にある. 測器は高さ約 $60 \mathrm{~m}$ のビルの上に立つ観 測塔の上，地上 $95.4 \mathrm{~m}$ に設置されており，かなり上空で 

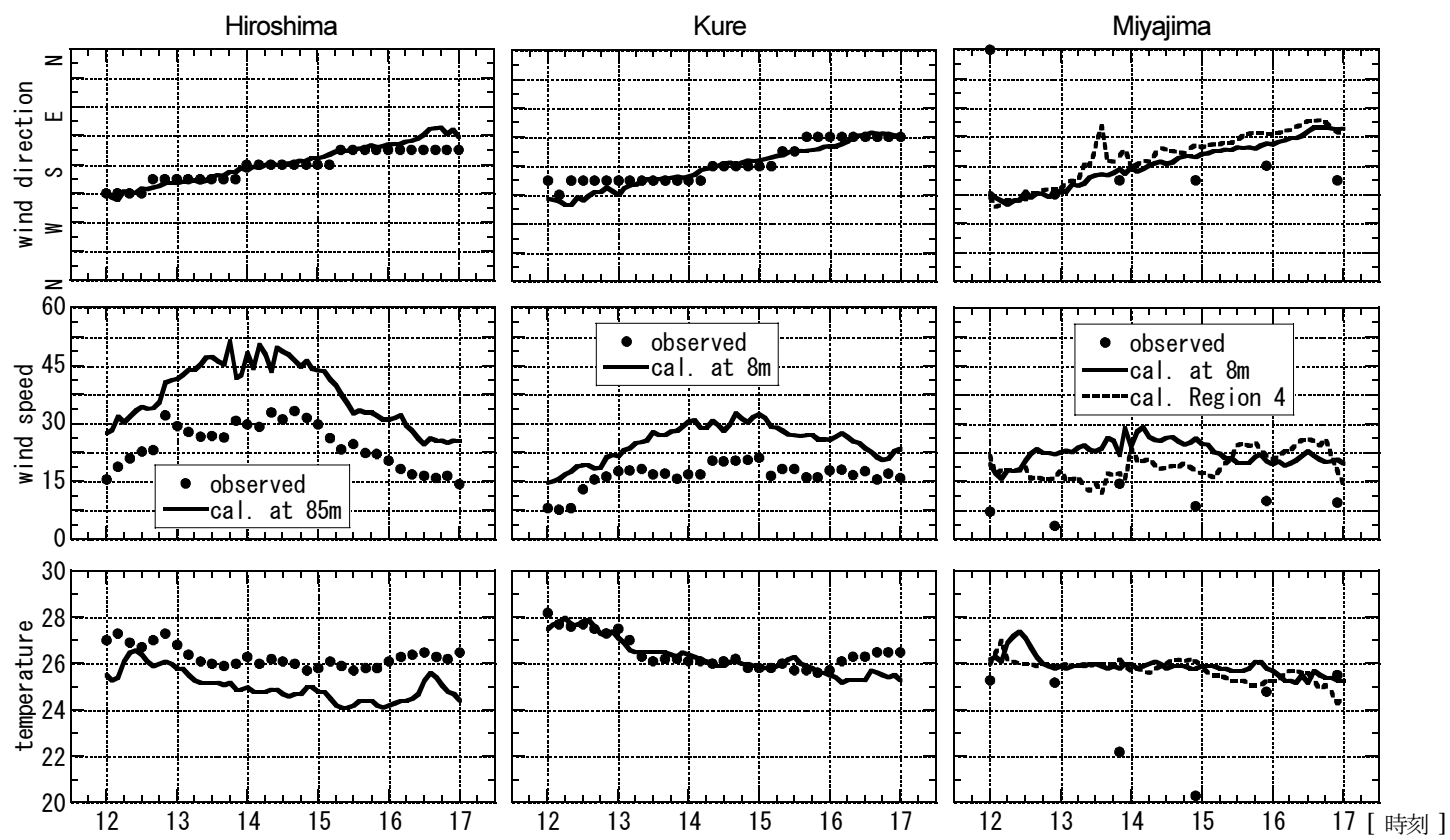

図 6 MM5 領域 3 の計算結果と観測值との比較（広島地方気象台，呉特別地域気象観測所および宮島消防署）

Fig.6 Comparison of simulated results of MM5 in region 3 with observed data around Hiroshima bay

の測定值となってはいるものの，周囲の市街地キャノピ 一の影響を受けていると考えられる。.また，吳のデータ は呉湾に面した呉海上保安部の屋上，地上 $17.4 \mathrm{~m}$ で観測 されているが，周囲には造船所などかなり粗い地表面粗 度が存在する. したがって, 広島や呉など市街地部で計 算に用いたラフネスパラメータが適当でない可能性があ る. 寸なわち, 領域 3 の計算で用いた粗度は，より大き なグリッドに対する土地利用の分類から引用したもので, 広範囲の平均值となっている，そのため, 領域 3 の格子 解像度に対応する粗度よりも滑らかな值を用いており，

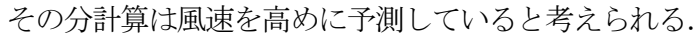
なお，計算で用いた USGS の土地利用区分では，都市域 における粗度長は $0.5 \mathrm{~m}$ である。 また, 内陸の広島地方 気象台における温度が観測值よりも低く計算されている 理由としては, 都市部における発熱量, 太陽からの熱放 射の授熱量が実際より低く計算されている可能性がある。 その他，計算上の台風の中心位置が気象庁の解析位置よ りも広島に近い，再現された中心気圧が気象庁の解析値 よりも低い，などが計算で風速を高く見積もっている原 因と考えられるが，定性的には図に示寸程度に妥当な結 果が得られている.

宮島については, 図 6 中領域 3 だけでなく領域 4 にお ける計算結果も示している. 最も細かな格子を用いた領 域 4 の結果は, より細かな時間変動を再現しているが,
観測値とはいずれもよい一致を示さない，観測は厳島神 社から北に約 $150 \mathrm{~m}$ ほど離れた宮島町役場の屋根上約 $5 \mathrm{~m}$ の鉄塔で行われ，すぐ東側には山の斜面が迫ってお り，実際の気流性状は周囲の地形の影響を大きく受けて いると考えられる. したがって，MM5 の領域 4 で用い た格子でも解像度が足りず，地形の影響が十分反映され ていないと考えられる. 気温は 14 時から 15 時にかけて 観測值が大きく下がっているが, 当時風雨が強く, 温度 センサーが雨で濡れた可能性もあると報告されている ${ }^{3)}$.

次に MM5 の解析領域 2 の結果を図 7 に示し, 台風の 接近・通過に伴う，やや広域的な風速場をみてみる. 11 時頃台風の中心が福岡の西にあるとき, 太平洋から備後 水道, 周防灘を通って宮崎県, 大分県沿岸を回り込むよ うにして台風の中心に吹き込む経路において，また，14 時頃中心が山口県の北にあるとき, 備後水道から広島湾 を過ぎ，広島県および島根県西部を通って台風の中心に 吹き込む経路において.いずれの場合も摩擦の少ない海 上で風は増速し, 山口県および広島県沿岸部に強風が吹 き付けるかたちとなっている。これらは，それぞれ山口 市の山口情報芸術センターの屋根被害が発生した時刻, 㛜島神社の左楽房が倒壊した時刻に対応している.この ように, 今回の台風の進路は広域的な地形と影響しあっ て, 風速の増加を引き起こしていたことがわかる. 


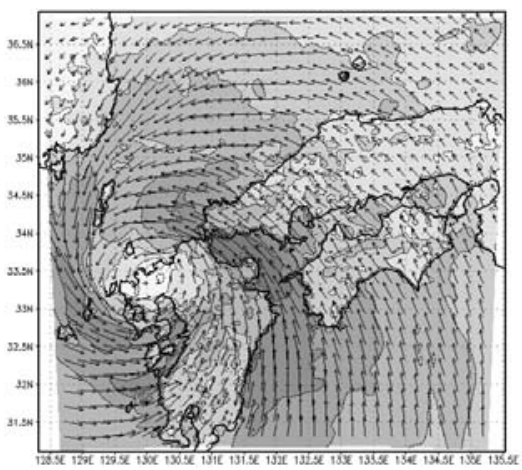

a. 11:00, Sep. 7

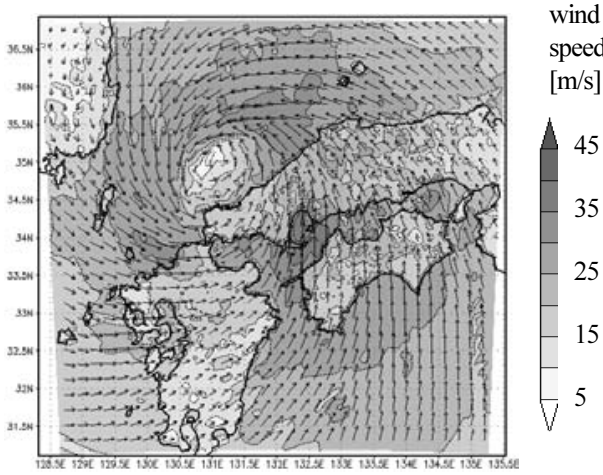

b. $14: 00$, Sep. 7

図 7 MM5 により計算された領域 2 における地上 $10 \mathrm{~m}$ 水平風速の分布

Fig.7 Contour map of horizontal wind speed at 10m over the ground and sea simulated by MM5 in Region 2
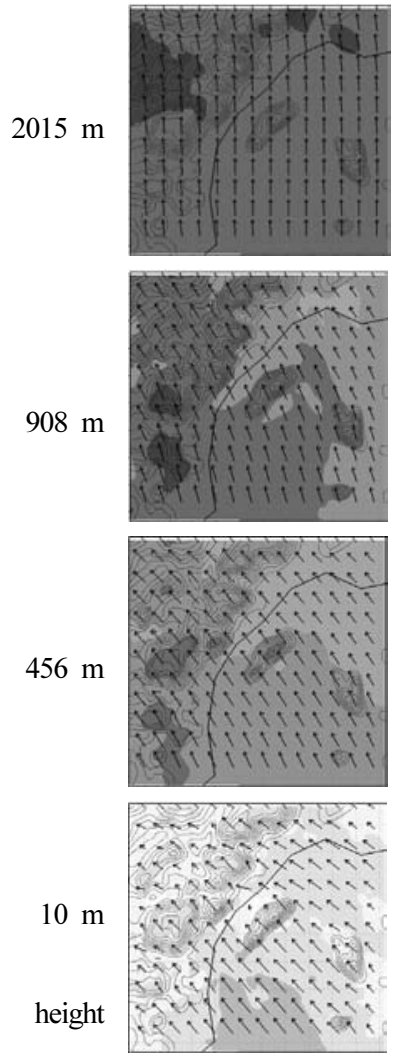

12:00
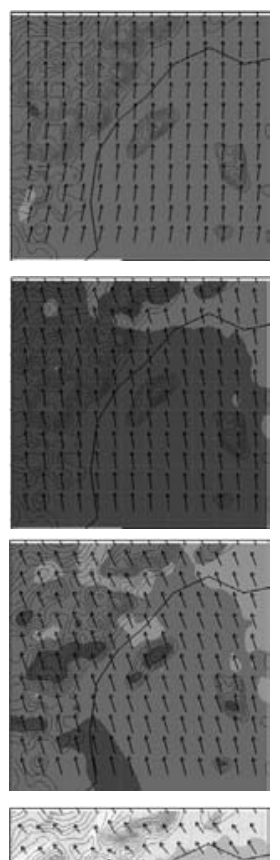

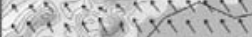

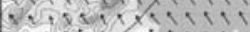
in inisilition

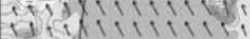
सी

13:00
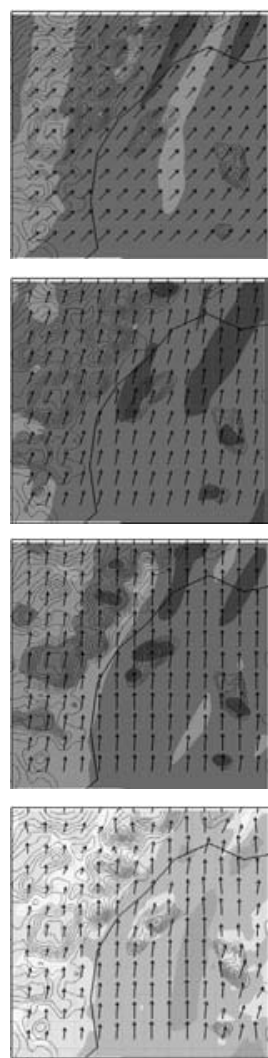

14:00
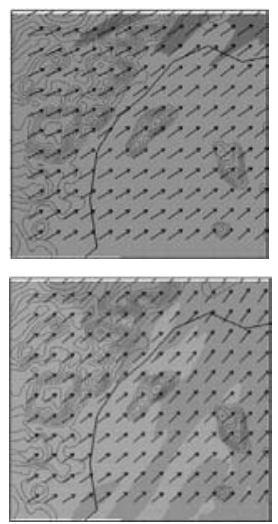

wind speed $[\mathrm{m} / \mathrm{s}]$

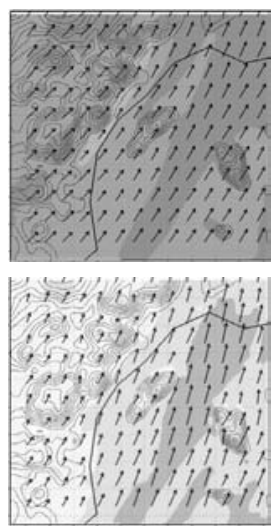

15:00

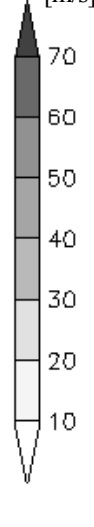

[ time ]

図 8 MM5 により計算された領域 4 における水平風速の分布 $(9$ 月 7 日）

Fig.8 Contour map of horizontal wind speed simulated by MM5 in Region 4 on Sep. 7

\section{2 宮島周辺の気流性状}

次に宮島周辺，広島湾沿岸の風速場の時間变化をみて みよう。MM5 計算領域 4 における台風通過時の風速場 を図 8 に示寸. 地上付近では 12 時から 15 時にかけて風 向が南東から南西に変化し，14 時頃にはほぼ南風が吹い ている．風向は高さ方向にも変化し，上空に向かって時
計回りに変化する. 地上付近の風速は 14 時頃が最も強 く, 高度 $900 \mathrm{~m}$ 付近では 13 時頃に最も強くなっている. 宮島上空では，風上側の山の斜面で風速増速域が，風下 側で減速域がみられるが，2000 m 付近ではその影響はほ とんどない. 図 9 に示寸広島での鉛直プロファイルの変 化をみると，風向は地上から $2000 \mathrm{~m}$ までの間でおおよ 


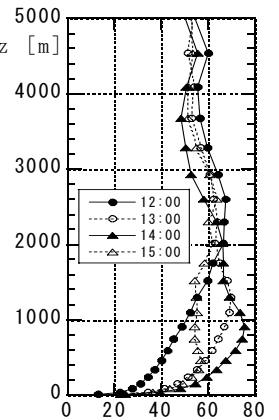

wind speed $[\mathrm{m} / \mathrm{s}$ ]

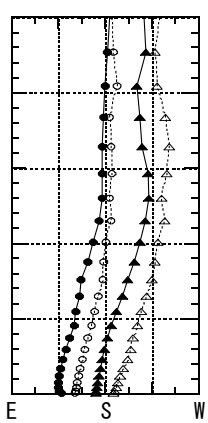

wind direction

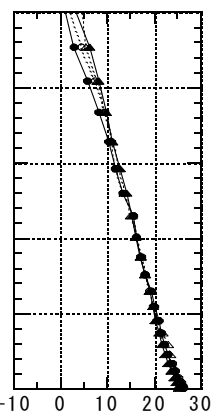

temperature $\left[{ }^{\circ} \mathrm{C}\right]$
図 9 MM5 領域 $3 の$ 計算結果

広島における風速, 風向, 温度の鉛直プロフィル

Fig.9 Profiles of wind speed, wind direction and temperature

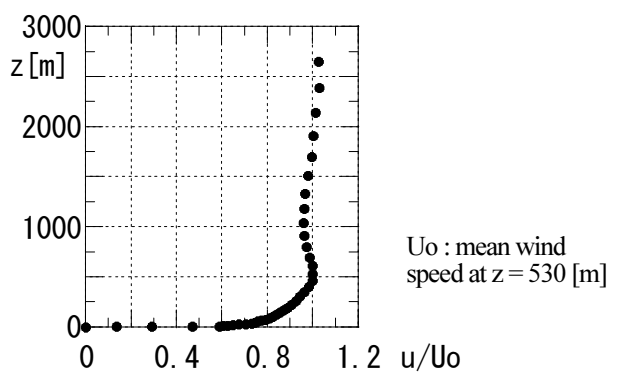

図 10 LES における流入境界面の風速の鉛直分布

Fig. 10 Mean wind speed profile at the inlet boundary for LES

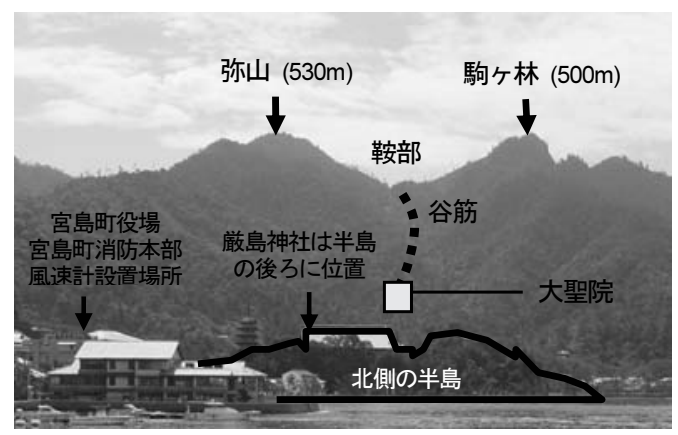

写真 1 北側の港から厳島神社に向かって南側を眺める

Photo 1. View of mountains and valleys to the south of Itsukushima Shrine from the northern port

そ 50 度ほど時計回りに変化し，それより上空ではほぼ 一定である. 風速は, $1000 \mathrm{~m}$ から $2000 \mathrm{~m}$ で極大となっ ている. 12 時から 15 時までの地面付近の風速勾配はべ き指数で約 0.2 , 粗度長は $0.6 \sim 1.0 \mathrm{~m}$ であった. 温度は地 上 $600 \mathrm{~m}$ 付近で勾配が変化するが，高さ方向にほぼ直線 的に下がっている. 計算で得られた湿度は地上 $600 \mathrm{~m}$ 以 上では飽和状態となっており, その前後が温度勾配の変 化に対応している，また，図は示さないが，温度，湿度 および気圧から求めた仮温位は地上付近で高さ方向にほ
ぼ一定となり，大気はほぼ中立であることを示していた．

\section{3 厳島神社周辺の気流性状}

3.1 で述べたように, MM5 による領域 4 の計算では, 宮島での観測結果を再現できるほどに解像度が高くない. また，文献 3)に報告されているように，実際の気流は周 囲の地形の影響を受けて複雑に変化している. そこで, より詳細な解析を行うために, LES による非定常計算を 行った. 解析領域および格子形状は，2.3で述べたよう に, 厳島神社付近の地形の影響を解像できるようにより 詳細なものとした．流入境界面には，14 時における MM5 領域 4 の計算結果をもとに, 図 10 に示寸ような風 速分布を流入境界面に一様に与えた。計算に際して，大 気は強風中立状態として, 風速, 圧力以外の物理量は用 いていない，また，主流直角方向，鉛直成分および変動 成分は 0 とし, 高さ方向の風向変化はないとして主流方 向の風速勾配だけを与えている.

峳島神社の南側には, 写真 1 に示寸ように宮島で最も 高い弥山と駒ヶ林がそびえ，それらに挟まれた鞍部から 厳島神社に向かって谷筋が伸びている. 台風 0418 号の 際にはビデオ映像や被害の状況から，この谷筋を南から 厳島神社の方に向かって下降風が吹いていたことが確認 されている ${ }^{3)}$.さらに, 谷筋の途中にある大聖院では時 折上昇風が吹いていたとの証言もある ${ }^{3)}$. この谷筋は図 11 に示すように約 $16^{\circ}$ と急勾配なため, 大気が中立状態 なら山の風下側では風が剥離し, 下降風は吹きにくいと 考えられる. そのため, 大気は安定な成層状態であった との指摘もあるが，宮島付近の詳細な気象観測データが ないため, 実際の大気が中立状態であったかどうかはわ かっていない. 一方，3.2で示したように，MM5 の計 算結果によると，大気はほぼ中立状態であったことから， ここでは研究の第一段階として, 大気は強風中立状態と 仮定し，LES による計算を行った，そして，その状態に おいて地形性の斜面下降風が，厳島神社南側の山の斜面 で起きていたかどうかも併せて検討することとした.

LES によって求めた 14 時頃の地上 $10 \mathrm{~m} の$ 平均風速分 布（実時間で約 800 秒の平均值に相当）をみると, 図 11 に示すように厳島神社南側の谷筋において, 流れが剥離 することなく下降風が生じていることがわかる．ちなみ に，水平方向に等間隔 $200 \mathrm{~m}$ の粗い格子を用いて，13 時， 14 時, 15 時の各時刻における宮島の風上側の平均流入 風向に直交する座標系を用いた予備計算を行い，流れ場 の概略を事前に確認したが，接近流の風向が南になる 14 時頃に谷筋に沿った流れが最も明瞭にできることがわか っている. 


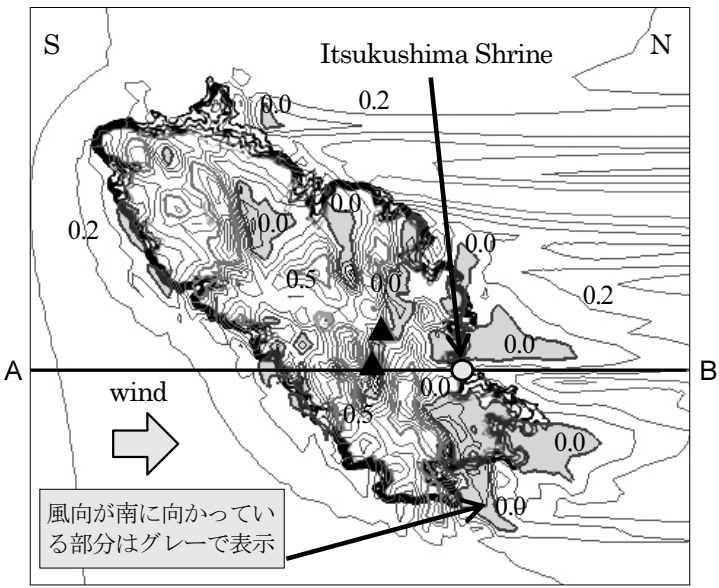

a. 海上・地上 $10 \mathrm{~m}$ の平均風速分布; 等值線の間隔は $0.1 \mathrm{u} / \mathrm{Uo}, \mathrm{u}$ は南北方向の平均風速, Uo は流入位置 における弥山の高さ $530 \mathrm{~m}$ での平均風速

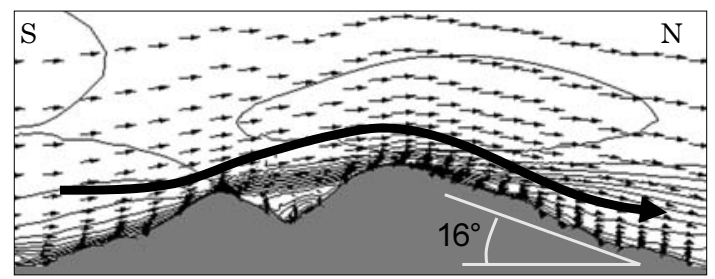

b ．厳島神社の南側に伸びる谷筋に沿った上図 $\mathrm{a}$ の直線 $\mathrm{AB}$ における鉛直断面内の平均風速分布 山越えの下降流が再現されている

図 11 LES の計算結果（9月 7 日 14 時頃 $)$

Fig. 11 LES results of mean wind field around Miyajima Island at 14:00, Sep. 7
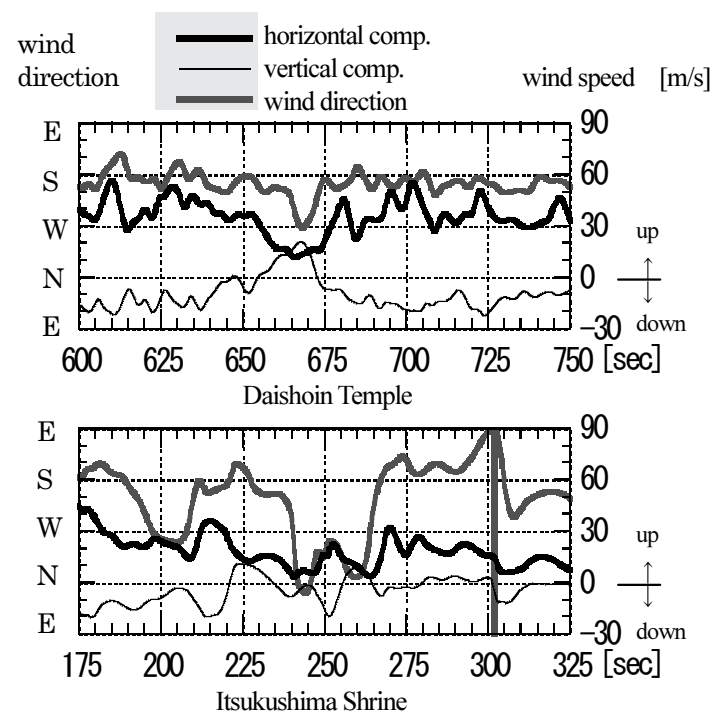

図 12 LES により計算された大聖院および厳島神社におけ る地上付近 $(10 \mathrm{~m})$ の風向・風速の時間変化

Fig. 12 Time variation of wind velocities by LES near the ground at $10 \mathrm{~m}$

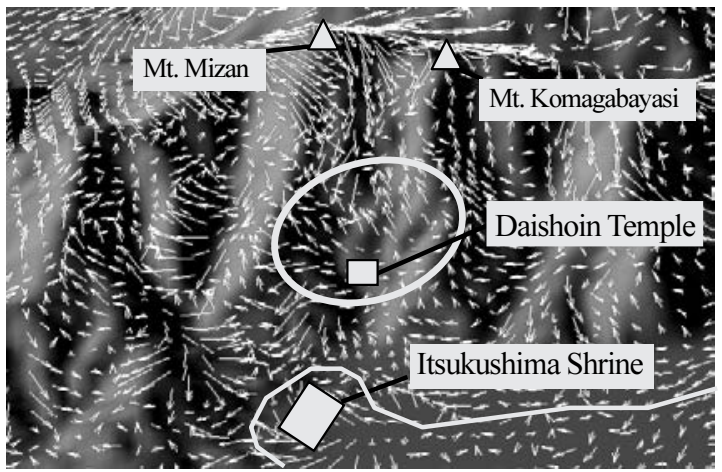

a . 地上付近（約 10m）における瞬間風速ベクトルの分布

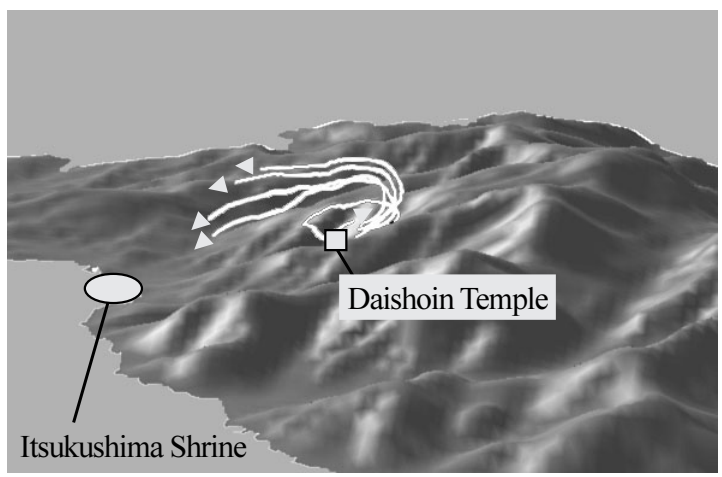

b．大聖院付近の流線を西南西から眺める

図 13 大聖院周辺で上昇風が吹いているときの瞬間風速場

Fig. 13 Instantaneous wind velocity field when updraft occurs around Daishoin Temple

谷の途中の大聖院および厳島神社付近における特徵的 な風向・風速の時間変化を図 12 に示す. 大聖院では南 風の下降風が吹くことが多いが，ときおり上昇風も発生 し, その場合, 南から西に風向が変化して上昇風となる ことが多い. 図 13 に示寸大聖院付近で上昇流が発生し ている事例をみると, 図 13 a のように上昇流を伴った西 北風の塊があり，付近の流線は地面付近から上方に向か うが，図 $13 \mathrm{~b}$ のように，ある程度上昇すると，上空の南 風に流されて北側，風下側で下方に向かう．LES により 計算された風速場の時間・空間変化をみると，この上昇 流を伴った西北風の塊は，尾根を越えた西側の谷に西か ら吹き込んできた気流の一部が上昇流を伴った気流の塊 となって，大聖院の西側の尾根を越えて移流してきたも のである.

一方, 厳島神社では南風が多いが, 西, 東, 北風も発 生し，北風の場合は風速が低くなる．風向変化はかなり 頻繁に起こり，風向角の変化は急である．厳島神社付近 で，東風，南風，西風が吹く場合の地上付近の瞬間風速 場の典型的な例を図 14 に示寸。東風が吹く場合（図 14 


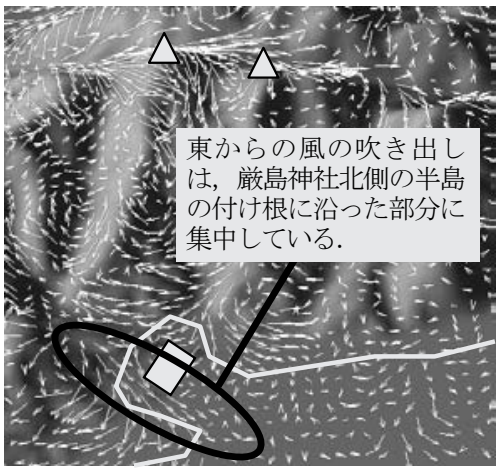

a．東風が吹いているとき

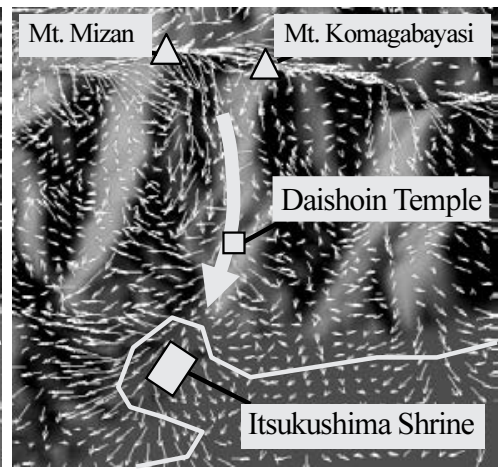

b．南風が吹いているとき

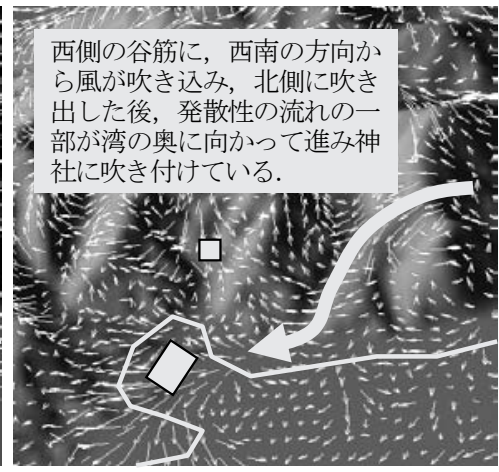

c．西風が吹いているとき

図 14 峳島神社周辺の地上付近（約 $10 \mathrm{~m} ）$ における瞬間風速ベクトルの分布

Fig. 14 Instantaneous wind velocity vector fields around Itsukushima Shrine at $10 \mathrm{~m}$

a ）は，峳島神社の東側，神社に向かって東西に伸びる 谷筋に沿って, 東から吹いてきた風が吹き出している. この吹き出しの強風域は狭く, 厳島神社北側に張り出し ている半島の付け根付近を集中して通過するため, その 部分でのシア一が大きくなっている，これは，強風被害 調査で, 東風のときに竜巻のように渦が巻いていたとの 証言 $^{3)}$ に符合する可能性がある. 南風が吹く場合（図 $14 \mathrm{~b}$ ）は，南側に伸びる谷筋を大聖院の方から吹き降り てきた気流塊がそのまま神社の方に吹き付ける形となっ ている場合が多い，西風が吹く場合（図 $14 \mathrm{c}$ ）は，神社 南側に伸びる谷筋よりも一つ西側の谷筋に, 西南の方向 から風が吹き込み，そのまま北側に吹き出した後，発散 性の流れの一部が, 東向き, 湾の奥に向かって進み厳島 神社に吹き付けている.

\section{4. 考察}

ここでは得られた計算結果をもとに各種考察を行うと ともに，計算上の問題点を検討する.

\section{1 広域的な地形と風の吹き方}

台風の中心位置と陸地, 山脈, 海などの広域的な地形 との位置関係により, 風速の増減が起こる. とくに, 台 風の中心に向かって吹き込む風が陸に挟まれた海上を通 るときには，風速は減速されることなく，場合によって は増速されて, 強風が沿岸部に吹き付ける場合がある. 今回解析した台風 0418 号のように, 台風の中心が九州 に上陸し，日本海に抜けるコースをたどるときに広島湾 沿岸部で強風が吹き被害が大きくなるのも代表的な事例 で，過去の㛜島神社の強風被害報告に指摘されている内 容と符合する.

\section{2 最大風速分布と被害率}

今回得られた計算結果を用いた応用例として, MM5
によって計算された最大風速分布と被害率との対応を検 討してみる. 図 15 に示古台風の接近から通過後に至る 間の最大風速の分布をみると, 広島湾沿岸から広島市, 東広島市, 広島県北西部の島根県との県境付近にかけて 強風域が広がっている. 図 16 に示すように, 対応する 広島県下での人的および建物の被害率の高い地域は, 最 大風速分布とよい対応を示しており, 計算結果の被害予 測への応用が期待される. MM5 で得られる風速の平均 化時間がどれくらいであるかは，格子解像度などの計算 条件により変化するため, 正確な值を決めることは困難 であるが, 風速変動のスペクトル解析などから十数分程 度の時間平均值と考えてよい.したがって, 実際に観測 されている 10 分間平均風速や瞬間最大風速との対応が どの程度になるのかを観測值などとの比較により検討す ることが今後の課題である.

\subsection{MM5 を用いた計算に関する今後の課題}

MM5 に関する今後の検討課題としては, 地面境界条 件の与え方が挙げられる. とくに, 市街地における粗度 の与え方は地面付近の摩擦抵抗の值に大きな影響を与え, 上空の風速の予測結果を左右するので, 格子解像度に応 じて，できるかぎり現実に対応した值を用いなければな らないと考えられる. また, 粗度形状の大きな都市部で は，市街地キャノピーの影響を取り込むことのできる境 界層スキームを用いることも検討す心゙きである，さらに， 今回の計算では, 海面温度は気象庁の日平均表面水温を 与え, 地表面での熱収支は，太陽放射と地表面過程を計 算している.ただし，地表面の特性は USGS の植生およ び土壌区分データにより与えているので, 詳細な格子を 用いる内側の計算領域に対しては解像度が粗いと考えら れる. とくに, 都市部のように, 地表面粗度の影響や温 熱変化が激しい場所ではより解像度の高い境界条件を与 


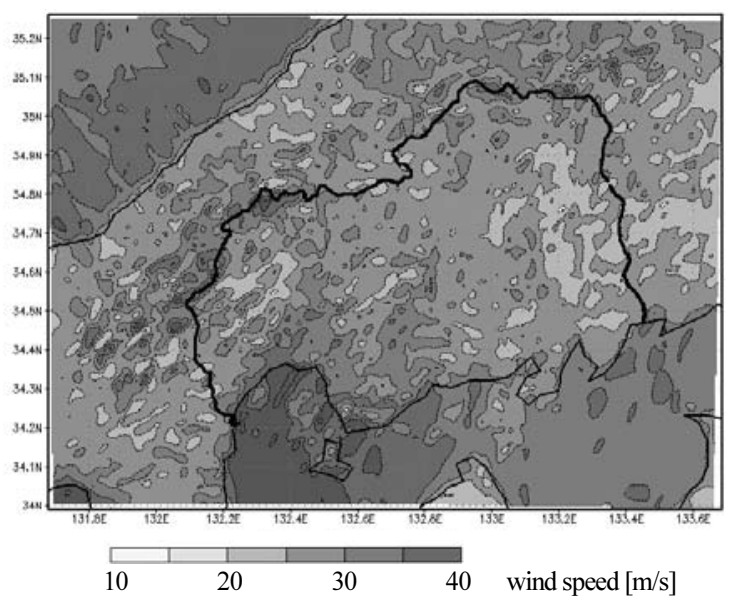

図 15 MM5 で計算された地上 $10 \mathrm{~m}$ における最大風速の分布

Fig.15 Contour map of maximum mean wind speed at $10 \mathrm{~m}$ by MM5

えることが望まれる.

\subsection{LES における各種計算条件の問題}

今回の LES による解析では流入境界条件として勾配 流れを与えているが，各高度で風速は一定值として乱れ の影響は考慮していない，宮島までにいくらかの吹送距 離があるので，海上付近で乱れが起きていること．乱れ がある場合の方が，山の風下斜面での付着がより促進さ れることから，今回のように流入風に乱れのない解析で も背面の下降風が起こるのであれば, 乱流流入条件にお いても下降風は起こると考えられる，さらに，流入境界 面における高さ方向の風向変化も無視しているが,

MM5 で計算された程度の風向変化であれば，今回主に 検討した山の風下側における地形性の乱流場に関して大 きな影響を与えないと考えている，もちろん，乱れや高 さ方向の風向変化が解析結果にどれほど影響するかは, さらに詳細な格子を用いた計算などとあわせて今後検討 する予定である．また，樹木や市街地部の地表面粗度の 取り扱いについても重要な検討課題として残されている。 さらに，今回の計算では宮島の北西方向，対岸の地面の 起伏は無視しているが，MM5 による広域の計算結果を みる限り, 14 時の南風の場合には風下側となって, LES の解析領域内で対岸の地形の影響はあまりないと思われ る。しかし，その他の時刻で，流入気流性状に対岸の地 形の影響が現れる場合には検討課題となろう。

\section{5. まとめ}

本研究では台風 0418 号通過時の強風場について, PSU/NCAR MM5 およびラージエディシミュレーション （LES）を用いて，日本列島をほぼカバーする大スケー
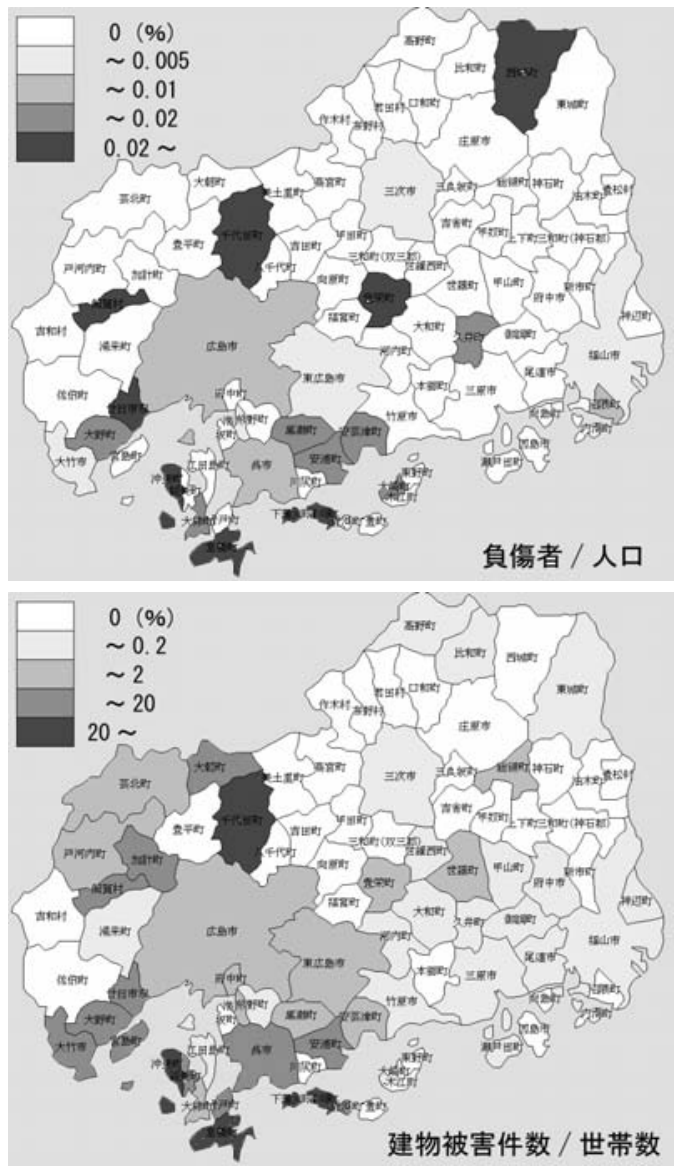

図 16 台風 0418 号による広島県内の人的・建物被害率の分布

Fig. 16 Distribution of human and house damage rate by Typhoon Songda in Hiroshima prefecture

ルから，宮島周辺の地形による局地的な風の乱流場を再 現できる程度の小スケールにわたる数值シミュレーショ ンを行った。計算結果は気象観測值や被害調査結果など との比較を行い，その有用性や問題点を検討した. 得ら れた結果をまとめると,

$1:$ 台風の経路および中心に向かって吹き込む風の流れ と，陸や海，山脈など広域的な地形の影響によって 広島湾沿岸部に吹き付ける強風の発生機構を明らか にできた.

2 ：LES を用いた宮島周辺の非定常乱流場の計算により， 強風中立状態においても，綮島神社南側の斜面下降 風が発生すること．厳島神社周辺において地形の影 響により, 風向・風速が複雑に変化する様子を捉え ることができ, 風向別の特徴を明らかにした. 今回 の計算では, 大気の安定度, 流入境界面の乱れや風 向変化を取り込んでいないが，検討対象と解析条件 を適切に設定すれば, 種々の計算条件を現実と同じ 
ように詳細に設定しなくても有用な結果を得ること ができることを示している，もちろん，種々の条件 の結果に及ぼす感度解析を行うことは, 今後の課題 として残されている.

4: MM5 の計算により得られた最大風速分布と強風に よる人的・建物被害率がよい対応を示すことを明ら かにし，計算結果の被害予測への応用が可能である ことを示した.

5 ：MM5 および LES を用いて計算を行う場合に，それ ぞれ地面境界条件や流入境界条件など, 改善すべき 計算上の問題点を明らかにした.

なお，本論文は参考文献 8)で発表した内容に追加計算を 行い，加筆，再構成したものである.

\section{謝 辞}

本研究の一部は科学研究費補助金の援助を受けて行われ た.

\section{参考文献}

1）花井正美・三浦正幸・玉井宏章 : 台風 9119 号によ る宮島・厳島神社の被害について, 平成 3 年度文 部省科学研究費突発災害研究成果報告, 総合研究 (A)03306022, 1992 年 8 月, pp. 129-166.
2）西村宏昭・谷池義人：台風 9918 号に伴う広島県下 の建物被害, 平成 11 年度科学研究費補助金研究 成果報告書, 課題番号 11800014 , 平成 12 年 6 月, pp.151-156.

3）丸山 敬 - 河井宏允 - 益田健吾 - 田村幸雄 - 松井 正宏 : 台風 0418 号による厳島神社の被害について, 日本風工学会論文報告集, No.102, 2005.1, pp.49-56.

4) Dudhia, J. : A nonhydrostatic version of the Penn StateNCAR meso-scale model: Validation tests and simulation of an Atlantic cyclone and cold front, Mon. Wea. Rev., 121, 1993, pp.1493-1513.

5）石川裕彦：台風にともなう強風はモデルでどの程 度再現できるか?, 日本風工学会誌, No.102, 2005.1, pp.19-22.

6）橋本篤・大澤輝夫・安田孝志 : 複雑地形上でのメ ソ気象モデル MM5 の風況計算精度と高解像度化の 限界に関する検討，日本風工学会論文集，No.104， 2005. 7, pp.65-74.

7）内田孝紀・杉谷賢一郎・大屋裕二 : 一様流中に置 かれた急峻な単純地形まわりの気流性状の評価, 日本風工学会論文集, No.100, 2004.7, pp.35-43.

8）丸山 敬 - 石川裕彦 - 内田孝紀 - 河井宏允 $\cdot$ 大屋 裕二: 台風 0418 号通過時の宮島周辺気流の数值シ ミュレーション, 日本風工学会誌,No.103, 2005.4, pp.101-102. 